\section{Biometric characterization and tetrazolium test in Campomanesia phaea O. Berg. Landrum seeds}

\author{
Aparecida Leonir da Silva ${ }^{1^{*}}$ D, Mariane Jeronimo Forte ${ }^{1}$ D, Angelo Pedro \\ Jacomino $^{1}\left(\mathbb{D}\right.$, Victor Augusto Forti ${ }^{2}$, Simone Rodrigues da Silva ${ }^{1}$ iif
}

\begin{abstract}
Campomanesia phaea has commercial interest because its fruits are used in the manufacture of several products, besides its high nutritional potential. Nevertheless, it has low germination potential and there is not much information in the literature. The aim of this study was to perform a biometric characterization and to establish the tetrazolium test for cambuci seeds. Seeds obtained from two collection periods were subjected to biometric evaluations (seed length, thickness, width and mass), water content, determination of the soaking curve and tetrazolium test. The soaking curve was performed with non-scarified seeds and seeds subjected to two scarification methods, mechanical and chemical. The tetrazolium test was performed soaking the seeds in a solution of 2, 3, 5 triphenyl tetrazolium chloride salt at 0.75 , 1.00 and $1.50 \%$ for 4,8 and 12 hours. After this period, the seeds were categorized as viable and non-viable. It was concluded that the cambuci seeds presented biometric differences between the two collection periods, because of the different water contents. There was no difference in the soaking curve among the three treatments tested and the solution of $0.75 \%$ for four hours in a water bath at $38^{\circ} \mathrm{C}$ was considered the best for performing the tetrazolium test.
\end{abstract}

Index terms: seed viability, soaking curve, Campomanesia phaea, germination test.

\section{Caracterização biométrica e teste de tetrazólio em sementes de Campomanesia phaea O. Berg. Landrum}

RESUMO: Campomanesia phaea possui interesse comercial devido aos seus frutos serem utilizados na fabricação de vários produtos, além do seu alto potencial nutricional. No entanto, possui baixo potencial germinativo e há pouca informação na literatura. $O$ objetivo desse trabalho foi caracterizar biometricamente e estabelecer o teste de tetrazólio para sementes de cambuci. Sementes provenientes de duas épocas de coleta foram submetidas a avaliações biométricas (comprimento, espessura, largura e massa de sementes), teor de água, obtenção da curva de embebição e teste de tetrazólio. A curva de embebição foi realizada com sementes não escarificadas e sementes submetidas a dois métodos de escarificação, mecânica e química. 0 teste de tetrazólio foi realizado com embebição das sementes em solução de sal cloreto de 2, 3, 5 trifenil tetrazólio a 0,75; 1,00 e 1,50\% durante 4, 8 e 12 horas, classificando-as como viáveis e inviáveis. Conclui-se que as sementes de cambuci apresentaram diferenças biométricas entre as duas épocas de coleta, devido aos diferentes teores de água. Nenhuma diferença ocorreu em relação à curva de embebição para os três tratamentos avaliados e a solução de $0,75 \%$ durante quatro horas em banhomaria, à $38^{\circ} \mathrm{C}$, foi considerada a melhor para realização do teste de tetrazólio.

Termos para indexação: viabilidade de sementes, curva de embebição, Campomanesia phaea, teste de germinação.
Journal of Seed Science, v.43, e202143013, 2021

http://dx.doi.org/10.1590/ 2317-1545v43240073
*Corresponding author

Received: 6/24/2020. Accepted: 5/17/2021.

${ }^{1}$ Departamento de Produção Vegetal, Universidade de São Paulo/ESALQ, 13418-900 Piracicaba, São Paulo, Brasil.

${ }^{2}$ Departamento de Tecnologia Agroindustrial e Socioeconomia Rural, Universidade Federal de

São Carlos, Campus de Ciências Agrárias, 13604-900 - Araras, São

Paulo, Brasil. 


\section{INTRODUCTION}

The cambuci fruit tree (Campomanesia phaea O. Berg. Landrum), a species belonging to the family Myrtaceae, native to the Brazilian Atlantic Forest (Lorenzi et al., 2006; Landrum and Kawasaki, 1997), being found throughout the Southeast region (Minas Gerais, São Paulo, Rio de Janeiro) (Oliveira et al., 2020). Genera such as Eugenia, Campomanesia, Psidium, and Myrciaria are extremely relevant and include the species of greatest economic interest (Maluf and Pisciottano-Ereio, 2005).

The cambucizeiro has a stem with a peeling aspect, glabrous leaves or covered with trichomes and its fruits are disc-shaped, when ripe they have green coloring (Oliveira et al., 2020) has fruit which can be consumed in natura, in the form of jams, juices, among others, with high concentrations of ascorbic acid, minerals, fibers, flavonoids, sodium, potassium, phosphor, magnesium and calcium (Lorenzi, 2002; Vallilo et al., 2005; Bianchini et al., 2016; Tokairin et al., 2018), proven therapeutic effect (Wczassek et al., 2019), other study showed that phenolic compounds from cambuci have a potentially actions protecting mice from a high-fat, high-sucrose diet-induced glucose intolerance and adipose tissue inflammation (Donado-Pestana et al., 2015).

The fruits are unique in the genus, characteristically ovoid-rhomboidal with a horizontal ridge. They have a strong sweet scent but are extremely sour like lemons. The mature fruits are green, fleshy, soft and each fruit there are usually 1-4 seeds and only a few of these germinate. Seed germination and seedling development are very slow (Kawasaki and Landrum, 1997). The biometry of native species is of great relevance for the differentiation of these species in the field (Cunha-Silva et al., 2012). In addition, knowledge of the physical characteristics of the seed is important for its conservation and exploitation, addition to being a tool for the detection of genetic variability within a population of the same species (Silva et al., 2014).

Its seeds are oblate, pale-white and low and slow germination potential (Santoro et al., 2020), which can interfere in the occurrence of a probable dormancy in them (Lorenzi, 2002), although there are no works in the literature that can prove it. Dormancy prevents the germination of viable seeds, even if they are in favorable environmental conditions (Carvalho and Nakagawa, 2012; Cipriani et al., 2019) and it might have endogenous and exogenous causes, which may be beneficial, for extending the germination period until there are favorable conditions, consisting in a mechanism for species perpetuation (Marcos-Filho, 2015). Nonetheless, when the goal is seedling production, dormancy is an undesirable characteristic, since seedling germination and emergence will be slow and uneven, promoting a longer time of exposure to adverse conditions (Azerêdo et al., 2010).

In order to be successful in cambuci tree seedling production using seeds, it becomes crucial to correlate all aspects involved in germination (water, light, $\mathrm{pH}$, temperature, soil moisture, dormancy and viability), since this is one of the most important stages in plants life cycle (Cosmo et al., 2017; Ghaderi-Far et al., 2010).

To determine seed viability, the tetrazolium test can be performed (Brasil, 2009), which is faster in comparison with the germination test and provides a diagnosis of seed quality, such as the mechanical damages, those caused by insects and those from weathering in pre-harvest and from deterioration during storage (França-Neto and Krzyzanowski, 2019).

The tetrazolium is a test indirectly determines the respiratory activity in the seed tissues (França-Neto and Krzyzanowski, 2019). The test relies on the activity of dehydrogenase enzymes, which catalyze respiratory reactions in the mitochondria, glycolysis and citric acid or Krebs cycle. When a seed is in contact with the colorless the tetrazolium salt solution, the solution penetrates the seed tissues where it interferes with the reduction processes of the living cells by accepting a hydrogen ion. In the reduced form, the tetrazolium salt is a red-colored, stable, nondiffusible substance called triphenylformazan or formazan (França-Neto and Krzyzanowski, 2019).

The tetrazolium test enables the inference of the maximum germination potential of a seed lot without the need to wait until a certain physiological event occurs, streamlining decision-making in relation to sowing or not a seed lot for seedling production, something very relevant for native species, especially those which present dormancy. Given the importance of this test, studies aiming at establishing a methodology for its performance are necessary. Some 
parameters such as soaking time, tetrazolium salt concentration and soaking temperature might vary among species, mainly among the native ones, such as Helianthus annuus (Silva et al., 2013), Plinia cauliflora (Hössel et al., 2013), Acca sellowiana (Sarmento et al., 2013), Eugenia brasiliensis, Eugenia pyriformis (Lamarca and Barbedo, 2014), and Eugenia uniflora (Kaiser et al., 2014).

Considering the importance of biometric analysis and the potential for using tetrazolium for the previous assessment of the physiological potential of cambuci seeds, the purpose of this study was to perform a biometric characterization of seeds, as well as to establish the variables for the determination of the methodology of the tetrazolium test, aiming at verifying the viability of these seeds in a fast and trustworthy way.

\section{MATERIAL AND METHODS}

The fruits of cambuci (C. phaea O. Berg) were collected in the region of Vale do Paraíba, in the city of Natividade da Serra, SP $\left(23^{\circ} 31^{\prime} 27^{\prime \prime}\right.$ S, 45 $27^{\prime} 12^{\prime \prime}$ W, 720 meters) climate cwa (humid subtropical, with dry winter and hot summer (Alvares et al., 2014)), in two periods (5/7/2019 and 6/7/2019). The climate is humid subject to the Atlantic tropical mass (Gomiero et al., 2007). The fruits were collected from different matrices, from a commercial production batch and had the same color. The seeds were manually extracted from ripe fruit, washed in running water with the aid of a sieve and arranged in a single layer in an environment with no control of temperature and relative humidity of the air for superficial drying. The seeds were subjected to biometric evaluations (length, thickness, width and mass), water content, determination of the soaking curve and the tetrazolium test.

A total of five replicates of 200 seeds from each collection were used for the determination of length, thickness, width and mass, employing a digital pachymeter $(0.01 \mathrm{~mm})$ and a precision scale $(0.0001 \mathrm{~g})$. For length, the largest measure of the seed axis was considered, from base to apex; width and thickness were obtained in the largest portion. The biometric data were submitted to the $t$ Test, at $5 \%$ of probability and regarding the existence of a correlation among the parameters, the data were evaluated by the Spearman's Correlation Coefficient, all performed with the statistical program BioEstat 5.3.

To obtain the water content of the seeds in the different collection periods, the oven method was used, placing four replicates of fifty seeds in an oven at $105^{\circ} \mathrm{C}$ for 24 hours. The results were expressed on wet basis (Brasil, 2009).

In order to verify whether the seeds presented waterproof seed coat, as well as the time they would take to reach the end of phase II of the germination process, helping in the definition of the procedures for the tetrazolium test, soaking curves were determined for non-scarified seeds (control) and seeds subjected to two scarification methods, mechanical (perforation on the opposite side to the hilum) and chemical (immersion in 99\% sulfuric acid for one minute). A total of four replicates of 25 seeds for each treatment of the first collection were used, which were immersed in distilled water and maintained in chambers of the B.O.D. type at $25{ }^{\circ} \mathrm{C}$. Mass gain was determined every hour at the first 24 hours of soaking and every 24 hours until the end of the assay, always drying the seeds on absorbent paper before weighing. Soaking was considered as the rise in mass in relation to the initial mass. The data were subjected to an analysis of variance by the $\mathrm{F}$ test and the comparison of the means by the Tukey's test, at $5 \%$ of probability, by the statistical program BioEstat 5.3.

In the evaluation of the tetrazolium test, seeds from the two collection periods were used, which were immersed in distilled water for sixteen hours, in B.O.D. at $25^{\circ} \mathrm{C}$, to ensure that all were swollen. Each treatment was composed of two replicates of 25 seeds for each collection, which were cut longitudinally and immersed in a tetrazolium solution (2, 3, 5 triphenyl-tetrazolium chloride) at the concentrations of $0.75,1.00$ or $1.50 \%$, and maintained in water bath at $38^{\circ} \mathrm{C}$, for 4,8 or 12 hours. After these periods, they were washed in running water and stayed submerged in water until the moment of evaluation.

The seeds were examined regarding extension, position and intensity of the reddish tones and the presence of milky-white areas. The seeds whose embryo presented reddish/pinkish coloration were considered viable and those 
with white/milky coloration were considered non-viable. The data were subjected to an analysis of variance by the $\mathrm{F}$ test, and for the comparison of the means, to the Tukey's Test, at $5 \%$ of probability, by the statistical program BioEstat 5.3 , in a $3 \times 3$ factorial scheme ( 3 tetrazolium concentrations $\times 3$ soaking periods).

For the confirmation of the tetrazolium test, four replicates of fifty seeds from the first collection were treated with the fungicide Thiram 200SC ( $2.5 \mathrm{~mL}$ of the product for 1000 grams) and arranged to germinate in Germitest ${ }^{\circledR}$ paper, moistened with water, at the proportion of 2.5 times the weight of the dry paper (Brasil, 2009). The test was maintained in a chamber of the B.O.D type at $25^{\circ} \mathrm{C}$, for sixty days, with the germination percentage of these seeds (emission of $2 \mathrm{~mm}$ of radicle) being evaluated in the end. The Germination Speed Index (GSI) was calculated according to Maguire, 1962, and Average Germination Time (AGT) in days (Labouriau, 1983).

\section{RESULTS AND DISCUSSION}

The seeds derived from the second collection presented inferior values in all biometric variables; nevertheless, only thickness and mass were statistically different from those obtained in the first collection. Among the parameters evaluated, width was the most heterogeneous variable, with the highest values of standard deviation, whereas mass was the most stable, with the lowest values for this variable (Table 1).

According to the correlation analysis (Table 2), in the first collection there was no significant correlation among the variables; conversely, in the second collection there was a significant correlation between length and width of the cambuci seeds. The seeds presented a mean of $18.55 \%$ and $5.45 \%$ of water content, in the first and second collections,

Table 1. Mean of the measures of length $(\mathrm{mm})$, thickness $(\mathrm{mm})$, width $(\mathrm{mm})$ and mass $(\mathrm{g} / \mathrm{seed})$ of $C$. phaea seeds derived from the first and second collections.

\begin{tabular}{cccccccccc}
\hline & \multicolumn{2}{c}{ Length $(\mathrm{mm})$} & \multicolumn{2}{c}{ Thickness $(\mathrm{mm})$} & \multicolumn{2}{c}{ Width $(\mathrm{mm})$} & \multicolumn{2}{c}{ Mass $(\mathrm{g} / \mathrm{seed})$} \\
\cline { 2 - 10 } & $\begin{array}{c}1^{\text {st }} \\
\text { collection }\end{array}$ & $\begin{array}{c}2^{\text {nd }} \\
\text { collection }\end{array}$ & $\begin{array}{c}1^{\text {st }} \\
\text { collection }\end{array}$ & $\begin{array}{c}2^{\text {nd }} \\
\text { collection }\end{array}$ & $\begin{array}{c}1^{\text {st }} \\
\text { collection }\end{array}$ & $\begin{array}{c}2^{\text {nd }} \\
\text { collection }\end{array}$ & $\begin{array}{c}1^{\text {st }} \\
\text { collection }\end{array}$ & $\begin{array}{c}2^{\text {nd }} \\
\text { collection }\end{array}$ \\
\hline Mean & $7.14 \mathrm{~A}$ & $7.10 \mathrm{~A}$ & $2.10 \mathrm{~A}$ & $1.92 \mathrm{~B}$ & $6.63 \mathrm{~A}$ & $5.97 \mathrm{~A}$ & $0.040 \mathrm{~A}$ & $0.036 \mathrm{~B}$ \\
Maximum & 9.07 & 9.02 & 3.33 & 2.97 & 8.70 & 7.83 & 0.045 & 0.037 \\
Minimum & 5.49 & 5.57 & 1.35 & 1.06 & 4.13 & 4.11 & 0.034 & 0.035 \\
Standard Deviation & 0.05 & 0.13 & 0.05 & 0.01 & 1.4 & 0.12 & 0.004 & 0.001 \\
\hline
\end{tabular}

Means followed by the same letter do not differ from each other by the $t$ Test at $5 \%$ of probability.

Table 2. Spearman's correlation $\left(r_{s}\right)$ for the biometric variables of the $C$. phaea seeds derived from the first and second collections.

\begin{tabular}{ccc}
\hline Correlated variables & $\begin{array}{c}\text { st } \text { collection } \\
\mathrm{r}_{\mathrm{s}}\end{array}$ & $\begin{array}{c}2^{\text {nd }} \text { collection } \\
\mathrm{r}_{\mathrm{s}}\end{array}$ \\
\hline Length $\mathrm{x}$ width & 0.4033 & $0.4494^{*}$ \\
Length $\mathrm{x}$ thickness & 0.0308 & 0.0935 \\
Length $\mathrm{x}$ mass & 0.0591 & 0.0320 \\
Width $\mathrm{x}$ thickness & 0.0112 & 0.0896 \\
Width $\mathrm{x}$ mass & 0.0236 & 0.0183 \\
Thickness $\mathrm{x}$ mass & 0.0473 & -0.0079 \\
\hline
\end{tabular}

*Highly significant considering the value of $p$. 
respectively. This water loss it is a feature of orthodox seeds, represents a pre-programmed phase of drying (or desiccation) in seed maturation (Castro et al., 2004).

Biometric characteristics are important in the classification and evaluation of the quality of the seeds, since in some cases, those fully developed seeds are related to those with the biggest size, resulting in a higher germination percentage with the formation of more vigorous plants (Sarmento et al., 2018) since they have a better-formed embryo and a greater accumulation of reserves (Carvalho and Nakagawa, 2012), an important feature for the commercial production of seedlings of this species.

For this reason, classifying the seeds by size can be a technique used to standardize the emergence of seedlings and the size of the juvenile plants (Carvalho and Nakagawa, 2012), besides being an important tool to allow the identification of genetic variability inside populations of the same species and the correlations with environmental factors (Sarmento et al., 2018). According to Silva et al. (2014), the knowledge of fruit and seed biometry is a basic requirement to allow the conservation and exploration of a species. Many species have already been biometrically characterized; among them, species from the family Myrtaceae, such as, for instance, Campomanesia adamantium (gabiroba) (Dresch et al., 2013) and Acca sellowiana (goiabeira-serrana) (Sarmento et al., 2018).

In this work, water content was the main factor responsible for the difference in the size and mass of the cambuci seeds (Table 1), variables that can also be affected by the variation among fruit from individuals from the same species and in the same plant (Vaughton and Ramsey, 1998).

The non-scarified seeds (control), chemical (immersion in sulfuric acid for one minute) and physical (perforation on the opposite side to the hilum) scarification did not present differences in the soaking curves (Figures $1 \mathrm{~A}$ and $B$ ). Only in the four initial hours, in the seeds subjected to the physical scarification, soaking was lower, thus showing that this species does not present seed coat dormancy. Bewley and Black (1994) highlighted that the soaking capacity of the seeds is fundamental in the germination process, since water is a limiting factor and a poor absorption can compromise germination, which is composed of the soaking stages (phase I), activation of the metabolic processes and degradation of the reserves into simpler substances (phase II) and the beginning of the embryo's growth (phase III) (Costa et al., 2011).

The soaking curve (Figure 1A) determined the time of 16 hours for the cambuci seeds (when they had a water content of $14.7 \%$ in the control, $14.9 \%$ in the chemical scarification and of $15.2 \%$ in the physical scarification) as the ideal to perform the tetrazolium test, since in this period the seeds reached a plateau in water content, increasing slowly for a period known as the phase of preparation and activation of the metabolism, which are required for the embryo's development (Cardoso, 2004).

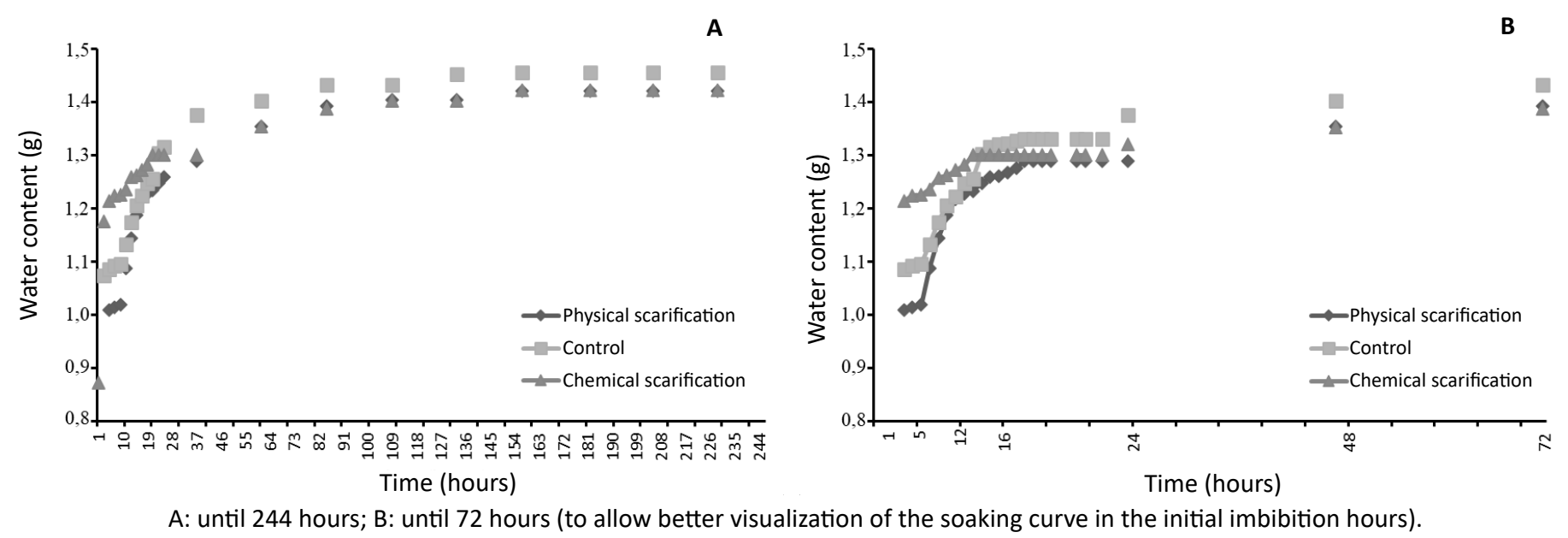

Figure 1. Soaking curve of the $C$. phaea seeds, without scarification (control), mechanical scarification (perforation on the opposite side to the hilum) and chemical scarification (immersion in sulfuric acid for one minute). 
A higher soaking time than that obtained in this work was reported for germination phase I in Psidium guineense seeds, which was of thirty hours (Santos et al., 2015). In Annona emarginata seeds, the change from phase I to phase II of germination only occurs when water content between $27.85 \%$ and $28.35 \%$ is reached (Costa et al., 2011), superior values to those found for cambuci seeds. For Campomanesia adamantium, phase I was of fifty hours and after seventy hours of soaking, there was primary root emission characterizing the end of phase II, which is considered short (LeãoAraújo et al., 2019).

The most used test to estimate seed viability is the germination test; nevertheless, in the Rules for Seed Testing (Brasil, 2009), information on the procedures for the conduction of this test for native forest species are scarce, requiring other rapid tests for the evaluation of seed viability. The establishment of an efficient methodology for the tetrazolium test becomes extremely important to perform a quick, economical and trustworthy test (Corte et al., 2010). Nonetheless, there was no information on the establishment of this test for cambuci, making it so important.

Based on the results obtained in the tetrazolium test, it was possible to divide the seeds into two classes regarding viability, according to the intensity, size and position of the color of the tissue and also the appearance of tissue of the seeds: viable seeds, those which presented reddish/pinkish coloration in the embryo and firm tissue (living and vigorous tissue); and non-viable seeds, those which presented milky-white coloration and also the presence of flaccid, soft tissues (dead tissue) (Figure 2) (Sarmento et al., 2013). The presence of only two classifications (viable and nonviable) was also found in other species, such as Araucaria angustifolia (Silva et al., 2016), Passiflora elegans (Silva et al., 2019), Piptadenia moniliformis (Azerêdo et al, 2011) and the hybrid Annona cherimola Mill. x Annona squamosa L. (Gimenez et al., 2014).

In the evaluation of the different concentrations of tetrazolium solution at the different coloration times, no statistical difference was observed among the concentrations $(0.75,1.00$ and $1.50 \%)$ and among the coloration times $(4,8$ and 12 hours) in the first and second collections (Tables 3 and 4). In the two collection periods, all tetrazolium concentrations $(0.75,1.00$ and $1.50 \%$,$) at the different times (4,8$ and 12 hours) were efficient for the evaluation of the test (Figure 2).

In the present study, the means of viable seeds were above $85 \%$ in the first collection and above $86 \%$ in the second. Nonetheless, around $12 \%$ of the seeds, in the first collection, remained without the presence of coloration, regardless of the concentration of the tetrazolium solution and of the time of reaction, thus demonstrating their nonviability. The data from the first period support those observed by the germination test, the latter had a germination of $89,0 \%$, the average germination time was 84,0 days and germination speed index was 1.56 days.

In Figure 3, the classification of the levels of viability established in the tetrazolium test are presented, and in A, B, $C, D, E$ and $F$ are the seeds classified as viable, and in $G, H, I, J$ and $K$ are the seeds classified as non-viable, presenting the milky-white coloration.

Table 3. Percentage of viability in C. phaea seeds derived from the first collection after 4,8 and 12 hours in tetrazolium solution at the concentrations of $0.75 \%, 1.00 \%$ and $1.50 \%$, respectively.

Time of soaking in the tetrazolium solution

\begin{tabular}{ccccccc}
\cline { 2 - 7 } Concentration & \multicolumn{3}{c}{ Viable (\%) } & \multicolumn{3}{c}{ Non-viable (\%) } \\
\cline { 2 - 7 } & $4 \mathrm{~h}$ & $8 \mathrm{~h}$ & $12 \mathrm{~h}$ & $4 \mathrm{~h}$ & $8 \mathrm{~h}$ & $12 \mathrm{~h}$ \\
\hline 0.75 & $78 \mathrm{Aa}$ & $88 \mathrm{Aa}$ & $90 \mathrm{Aa}$ & $22 \mathrm{Aa}$ & $12 \mathrm{Aa}$ & $10 \mathrm{Aa}$ \\
1.00 & $86 \mathrm{Aa}$ & $88 \mathrm{Aa}$ & $90 \mathrm{Aa}$ & $14 \mathrm{Aa}$ & $12 \mathrm{Aa}$ & $10 \mathrm{Aa}$ \\
1.50 & $92 \mathrm{Aa}$ & $86 \mathrm{Aa}$ & $92 \mathrm{Aa}$ & $8 \mathrm{Aa}$ & $14 \mathrm{Aa}$ & $8 \mathrm{Aa}$ \\
\hline General Mean & 85.3 & 87.3 & 90.6 & 14.6 & 12.6 & 9.3 \\
\hline CV (\%) & & 10.7 & & & & \\
\hline
\end{tabular}

*Same capital letters in the columns and lowercase letters in the lines do not differ from each other by the Tukey's Test at $5 \%$ of probability. 
Table 4. Percentage of viability in C. phaea seeds derived from the second collection after 4,8 and 12 hours in tetrazolium solution at the concentrations of $0.75 \%, 1,00 \%$ and $1,50 \%$, respectively.

\begin{tabular}{ccccccc}
\hline \multirow{2}{*}{ Concentration } & \multicolumn{5}{c}{ Time of soaking in the tetrazolium solution } \\
\cline { 2 - 7 } & $4 \mathrm{~h}$ & $8 \mathrm{~h}$ & $12 \mathrm{~h}$ & $4 \mathrm{~h}$ & $8 \mathrm{~h}$ & $12 \mathrm{~h}$ \\
\cline { 2 - 7 } & $88 \mathrm{Aa}$ & $76 \mathrm{Aa}$ & $90 \mathrm{Aa}$ & $12 \mathrm{Aa}$ & $12 \mathrm{Aa}$ & $10 \mathrm{Aa}$ \\
\hline 0.75 & $92 \mathrm{Aa}$ & $92 \mathrm{Aa}$ & $94 \mathrm{Aa}$ & $8 \mathrm{Aa}$ & $8 \mathrm{Aa}$ & $6 \mathrm{Aa}$ \\
1.00 & $94 \mathrm{Aa}$ & $92 \mathrm{Aa}$ & $96 \mathrm{Aa}$ & $6 \mathrm{Aa}$ & $6 \mathrm{Aa}$ & $4 \mathrm{Aa}$ \\
1.50 & 91.3 & 86.6 & 93.3 & 8.6 & 8.6 & 6.6 \\
\hline General Mean & 11.75 & & 73.8 & \\
\hline CV (\%) & & & & & & \\
\hline
\end{tabular}

*Same capital letters in the columns and lowercase letters in the lines do not differ from each other by the Tukey's Test at $5 \%$ of probability.

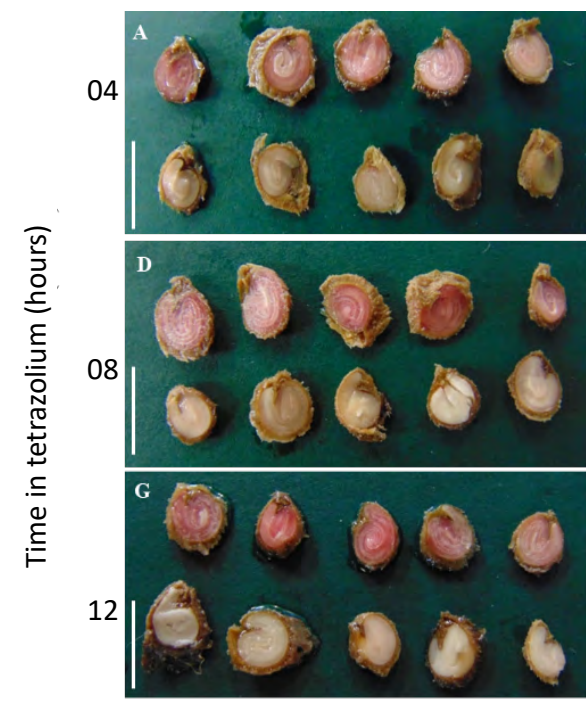

$0.75 \%$

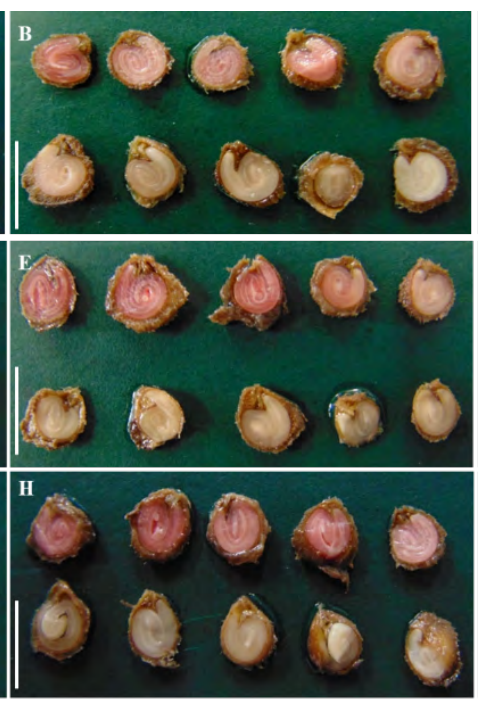

$1.00 \%$

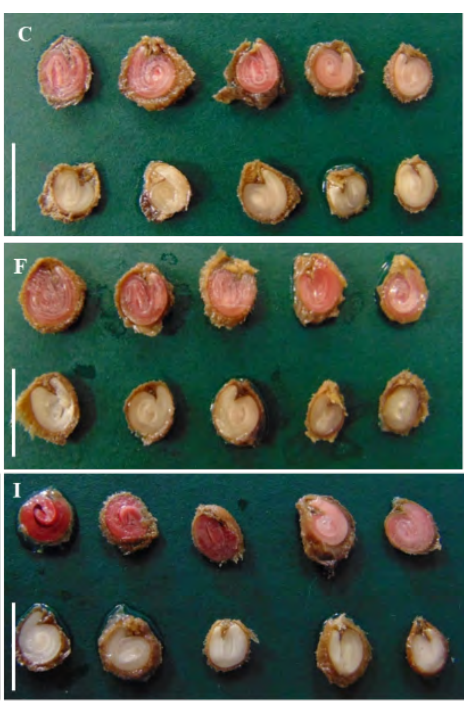

$1.50 \%$

Tetrazolium concentration

A, B and C: seeds after four hours in tetrazolium solution at the concentrations of $0.75 \%, 1,00 \%$ and $1.50 \%$, respectively. D, E and F: seeds after eight hours in tetrazolium solution at the concentrations of $0.75 \%, 1,00 \%$ and $1.50 \%$, respectively. $\mathrm{G}, \mathrm{H}$ and I: seeds after twelve hours in tetrazolium solution at the concentrations of $0.75 \%, 1,00 \%$ and $1.50 \%$, respectively. Viable seeds presenting reddish/pinkish coloration in the embryo (first row from the top to the bottom) and non-viable seeds with milky-white coloration (second row from the bottom to the top). $S \mathrm{cale}=1 \mathrm{~cm}$.

Figure 2. Classes of $C$. phaea seeds obtained in the tetrazolium test at different times and salt concentrations.

The concentration of the tetrazolium salt and the exposure time vary according to species. For seeds from Eugenia uniflora and Eugenia involucrata, the solution at $0.50 \%$ of tetrazolium for two hours was indicated (Kaiser et al., 2014; Cripa et al., 2014), for Eugenia brasiliensis, the concentration of $0.25 \%$ for three hours, and at $0.10 \%$ for two hours for the seeds from Eugenia pyriformis (Lamarca and Barbedo, 2014). For Tabebuia roseoalba, 0.05\% for 24 hours (Abbade and Takaki, 2014) and for Leucaena leucocephala, 0.15\% for two hours is recommended (Costa and Santos, 2010).

In the two collection periods, in all tetrazolium concentrations $(0.75,1.00$ and $1.50 \%$,$) and at the different times$ (4, 8 and 12 hours), the test was efficient for the evaluation of seed viability (Figure 2), a result supported by the germination test in the first period. Therefore, the authors indicate the use of tetrazolium at the concentration of $0.75 \%$ for four hours as the efficient methodology for cambuci seed viability, since the lowest concentration will use less tetrazolium salt, and with the shortest time, the test will be streamlined. 

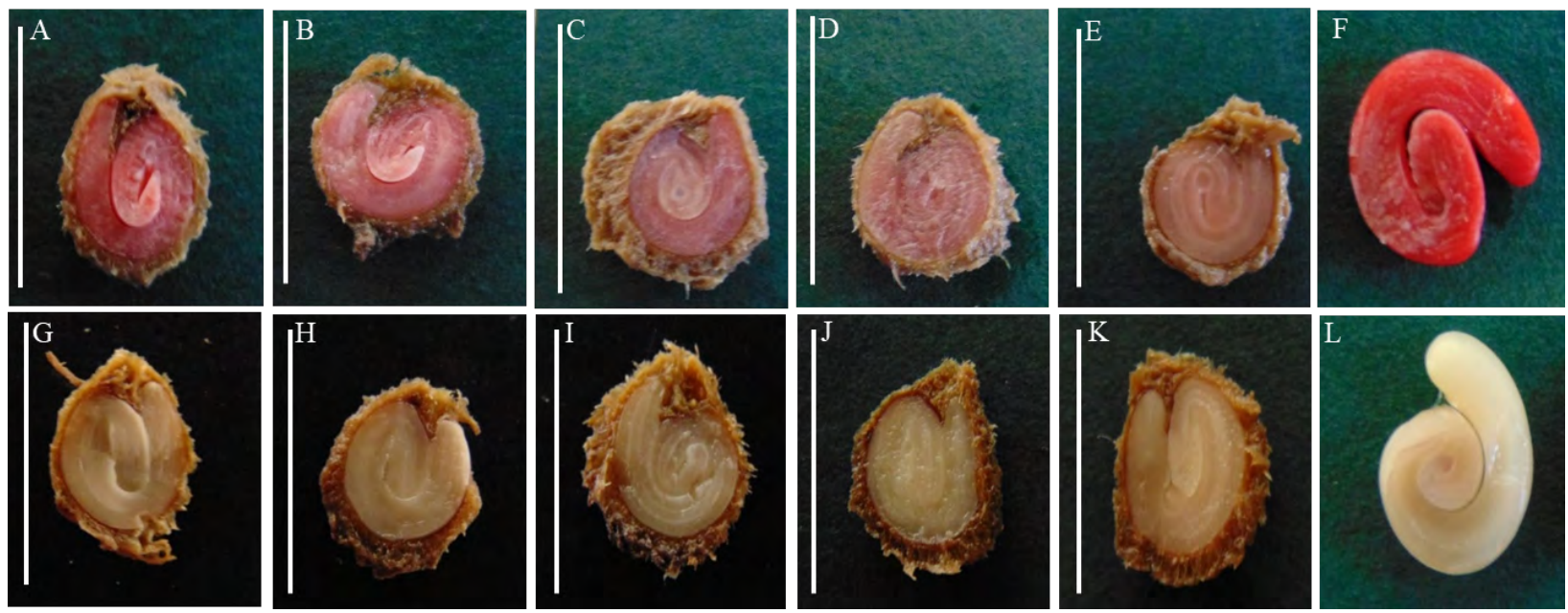

A, B, C, D, E and F: viable seeds presenting reddish/pinkish coloration in the embryo. G, H, I, J, K and L: non-viable seeds with milky-white coloration. Scale $=1 \mathrm{~cm}$.

Figure 3. Classes of $C$. phaea seeds obtained in the tetrazolium test.
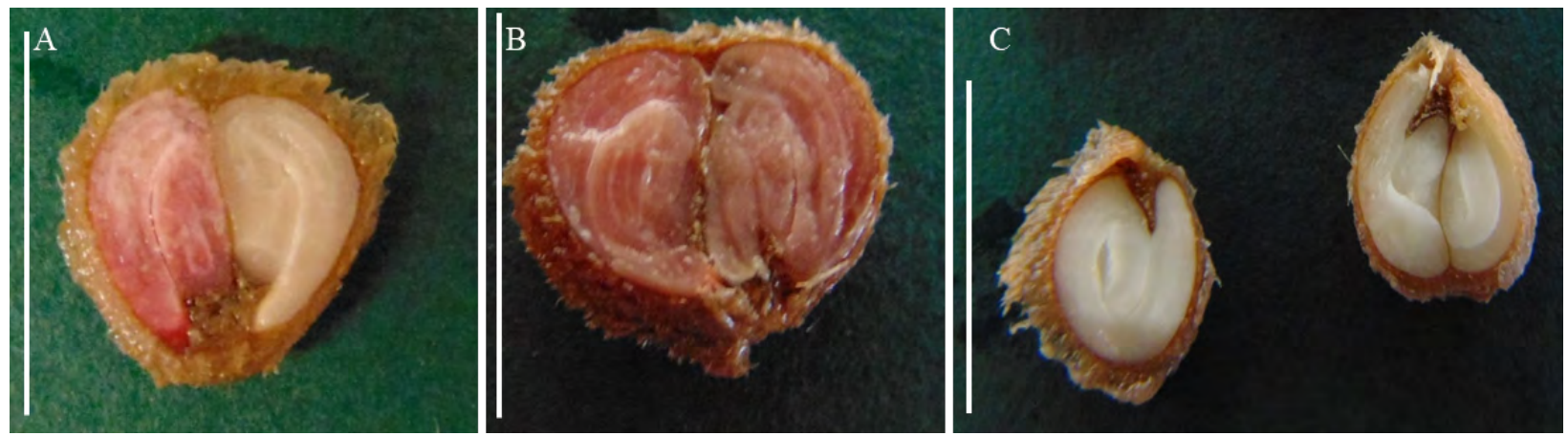

A: seeds with double embryo after the tetrazolium test, with one viable embryo and the other non-viable. B: seeds with double embryo after the tetrazolium test, with both embryos viable. C: cambuci seeds with one embryo and with two embryos. Scale $=1 \mathrm{~cm}$.

Figure 4. Classes of $C$. phaea seeds with double embryo.

The cambuci seeds presented a peculiarity, around $1.50 \%$ of the seeds presented double embryo. Evaluating the tetrazolium test, it was possible to observe that in the same double-embryo seed, one embryo was viable and the other, non-viable (Figure 4 A), or both embryos were either viable or non-viable (Figures 4 B and 4 C). Nevertheless, in the literature there are no reports on the occurrence of polyembryony in C. phaea; however, in species from the family Myrtaceae, cases of polyembryony can be observed, for instance, in seeds from malay apple (Syzygium malaccense) (Landrum and Kawasaki, 1997; Gurgel and Soubihe Sobrinho, 1951).

In summary, water content was the main factor responsible for the difference in the size and mass of the Campomanesia phaea seeds and the soaking curves showed that this species does not present seed coat dormancy. All tetrazolium concentrations at the different times were efficient for the evaluation of the test in cambuci seeds. So, the authors indicate the use of tetrazolium at the concentration of $0.75 \%$ for four hours, since the lowest concentration will use less tetrazolium salt, and with the shortest time, the test will be streamlined. 


\section{CONCLUSIONS}

The different water contents in the seeds of Campomanesia phaea are determinant in their biometric parameters, regardless of the period of collection.

The use of the concentration of $0.75 \%$ of the $2,3,5$ triphenyl tetrazolium chloride salt, for four hours, in water bath, at $38{ }^{\circ} \mathrm{C}$, is recommended to perform the tetrazolium test in cambuci seeds.

\section{ACKNOWLEDGEMENTS}

The third and the last authors thank the scholarship in Productivity in Research granted by the Conselho Nacional de Desenvolvimento Científico e Tecnológico (CNPq).

\section{REFERENCES}

ABBADE, L.C.; TAKAKI, M. Teste de tetrazólio para avaliação da qualidade de sementes de Tabebuia roseoalba (Ridl.) SandwithBignoniaceae, submetidas ao armazenamento. Revista Árvore, v.38, n.2, p.233-240, 2014. https://www.scielo.br/scielo. php?pid=S0100-67622014000200003\&script=sci_abstract\&tlng=pt

ALVARES, C.A.; STAPE, J.L.; SENTELHAS, P.C.; GONÇALVES, J.L.M.; SPAROVEK, G. Köppen's climmate classification map for Brazil. Meteorologishche Zeitschrift, v.22, n.6, p.711-728, 2014. http://www.lerf.eco.br/img/publicacoes/Alvares_etal_2014.pdf

AZERÊDO, G.A.; PAULA, R.C.; VALERI, S.V. Viabilidade de sementes de Piptadenia moniliformis Benth. pelo teste de tetrazólio. Revista Brasileira de sementes, v.33, n.1, p.61-68, 2011. https://www.scielo.br/scielo.php?script=sci_ arttext\&pid=S0101-31222011000100007

AZERÊDO, G.A.; PAULA, R.C.; VALERI, S.V.; MORO, F.V. Superação de dormência de sementes de Piptadenia moniliformis Benth. Revista Brasileira de sementes, v.32, n.2, p.49-58, 2010. https://www.scielo.br/scielo.php?pid=S0101-31222010000200006\&script=sci_arttext

BEWLEY, J.D.; BLACK, M. Seeds: physiology of development and germination. New York: Plenum, 1994. 445p.

BIANCHINI, F.G.; BALBI, R.V.; PIO, R.; SILVA, D.F.; PASQUAL, M.; VILAS BOAS, E.V.B. Caracterização morfológica e química de frutos de cambucizeiro. Bragantia, v.75, n.1, p.10-18, 2016. https://www.scielo.br/pdf/brag/v75n1/0006-8705-brag-1678-4499096.pdf

BRASIL. Ministério da Agricultura, Pecuária e Abastecimento. Regras para análise de sementes. Ministério da Agricultura, Pecuária e Abastecimento. Secretaria de Defesa Agropecuária. Brasília: MAPA/ACS, 2009. 399p. https://www.gov.br/agricultura/pt-br/ assuntos/laboratorios/arquivos-publicacoes-laboratorio/regras-para-analise-de-sementes.pdf/view

CARDOSO, V.J.M. Dormência: estabelecimento do processo. In: FERREIRA, A.G.; BORGHETTI, F. (org.). Germinação: do básico ao aplicado. Porto Alegre: Artmed, 2004. p.5.95-5.108.

CARVALHO, N.M.; NAKAGAWA, J. Sementes: ciência, tecnologia e produção. Jaboticabal: FUNEP, 2012. 590p.

CASTRO, R.D.; BRADFORD, K.J.; HILHORST, H.W.M. Desenvolvimento de sementes e conteúdo de água. In: FERREIRA, A.G.; BORGHETTI, F. (org.). Germinação: do básico ao aplicado. Porto Alegre: Artmed, 2004. p.51-67.

CIPRIANI, V.B.; GARLET, J.; LIMA, B.M. Overcoming dormancy in Chloroleucon acacioides and Senna macranthera seeds. Revista de Ciências Agrárias, v.42, n.1, p.51-60, 2019. http://www.scielo.mec.pt/scielo.php?script=sci_abstract\&pid=S0871-018X201900010 $0007 \& \operatorname{lng}=\mathrm{pt} \& \mathrm{nrm}=\mathrm{iso} \& \mathrm{t} \operatorname{lng}=\mathrm{en}$

CORTE, V.B.; BORGES, E.E.L.; PEREIRA, B.L.C. Adequação da metodologia do teste de tetrazólio para avaliação da viabilidade de sementes de Melanoxylon brauna Schot. Cerne, v.16, n.3, p.415-421, 2010. https://www.scielo.br/scielo.php?script=sci_ arttext\&pid=S0104-77602010000300018

COSMO, N.L.; GOGOSZ, A.M.; REGO, S.S.; NOGUEIRA, A.C.; KUNIYOSHI, Y.S. Morfologia de fruto, semente e plântula, e germinação de sementes de Myrceugenia euosma (O. Berg) D. Legrand (Myrtaceae). Revista Floresta, v.47, n.4, p.479-488, 2017. https:// revistas.ufpr.br/floresta/article/view/46933

COSTA, C.J.; SANTOS, C.P. Teste de tetrazólio em sementes de leucena. Revista Brasileira de Sementes, v.32, n.2, p.66-72, 2010. https://www.scielo.br/scielo.php?pid=S0101-31222010000200008\&script=sci_arttext 
COSTA, P.N.; BUENO, S.S.C.; FERREIRA, G. Fases da germinação de sementes de Annona emarginata (Schltdl.) H. Rainer em diferentes temperaturas. Revista Brasileira de Fruticultura, v.33, n.1, p.253-260, 2011. https://www.scielo.br/scielo.php?script=sci_ abstract\&pid=S0100-29452011000100031\&lng=pt\&nrm=iso

CRIPA, F.B.; FREITAS, L.C.N.; GRINGS, A.C.; BORTOLINI, M.F. Tetrazolium test for viability estimation of Eugenia involucrata DC. and Eugenia pyriformis Cambess. seeds. Journal of Seed Science, v.36, n.3, p.305-311, 2014. https://www.scielo.br/scielo. php?pid=S2317-15372014000300005\&script=sci_arttext

CUNHA-SILVA, G.R.; RODRIGUES, C.M.; MIRANDA, S.C. Dados biométricos de frutos e sementes de Hymenaea courbaril var. stilbocarpa (Hayne) Y. T. Lee \& Langenh e H. martiana Hayne. Revista Biotemas, v.25, n.3, p.1-7, 2012. https://periodicos.ufsc.br/ index.php/biotemas/article/view/2175-7925.2012v25n3p121

DONADO-PESTANA, C.M.; BELCHIOR, T.; FESTUCCIA, W.T.; GENOVESE, M.I. Phenolic compounds from cambuci (Campomanesia phaea $\mathrm{O}$. Berg) fruit attenuate glucose intolerance and adipose tissue inflammation induced by a high-fat, high-sucrose diet. Food Research International, v.69, p.170-178, 2015. https://www.sciencedirect.com/science/article/pii/S0963996914008205

DRESCH, D.M.; SCALON, S.P.Q.; MASETTO, T.E.; VIEIRA, M.C. Germinação e vigor de sementes de gabiroba em função do tamanho do fruto e semente. Pesquisa Agropecuária Tropical, v.43, n.3, p.262-271, 2013. https://www.scielo.br/pdf/pat/v43n3/a06.pdf

FRANÇA-NETO, J.B.; KRZYZANOWSKI, F.C. Tetrazolium: an important test for physiological seed quality evaluation. Journal of Seed Science, v.41, n.3, p.359-366, 2019. https://www.scielo.br/pdf/jss/v41n3/2317-1545-jss-41-03-359.pdf

GHADERI-FAR, F; GHEREKHLOO, J.; ALIMAGHAM, M. Influência de fatores ambientais na germinação e emergência de plântulas de trevo-amarelo (Melilotus officinalis). Planta Daninha, v.28, n.3, p.463-469, 2010. https://www.scielo.br/scielo.php?script=sci_ arttext\&pid=S0100-83582010000300002\&Ing=en

GIMENEZ, J.I.; FERREIRA, G.; CAVARIANI, C. Tetrazolium test for assessment of seed viability of atemoya (Annona cherimola Mill. x A. squamosa L.). Journal of Seed Science, v.36, n.3, p.357-361, 2014. https://www.scielo.br/scielo.php?pid=S2317$15372014000300012 \&$ script=sci_arttext\&tlng=en

GOMIERO, L.M.; SOUZA, U.P.; BRAGA, F.M.S. Reprodução e alimentação de Rhamdia quelen (Quoy \& Gaimard, 1824) em rios do Núcleo Santa Virgínia, Parque Estadual da Serra do Mar, São Paulo, SP. Biota Neotropica, v.7, n.3, p.127-133, 2007. https://www. scielo.br/scielo.php?pid=S167606032007000300015\&script=sci_arttext\&tlng=pt

GURGEL, J.T.A.; SOUBIHE SOBRINHO, J. Poliembrionia em mirtáceas frutíferas. Bragantia, v.11, n.4-6, p.141-163, 1951. https:// www.scielo.br/scielo.php?script=sci_arttext\&pid=S0006-87051951000200006

HÖSSEL, C.; OLIVEIRA, J.S.M.A.; FABIANE, K.C.; WAGNER-JÚNIOR, A.; CITADIN, I. Conservação e teste de tetrazólio em sementes de jabuticabeira. Revista Brasileira de Fruticultura, v.35, n.1, p.255-261, 2013. http://www.scielo.br/pdf/rbf/v35n1/29.pdf

KAISER, D.K.; FREITAS, L.C.N.; BIRON, R.P.; SIMONATO, S.C.; BORTOLINI, M.F. Adjustment of the methodology of the tetrazolium test for estimating viability of Eugenia uniflora L. seeds during storage. Journal of Seed Science, v.36, n.3, 2014. https://www.scielo.br/ scielo.php?script=sci_arttext\&pid=S2317-15372014000300010

KAWASAKI, M.L.; LANDRUM, L. A rare and potentially economic fruit of Brazil: Cambuci, Campomanesia phaea (Myrtaceae). Economic Botany, v.51, n.4, p.403-405, 1997.

LABOURIAU, L.G. A germinação das sementes. Washington: Secretaria Geral da Organização dos Estados Unidos Americanos, 1983. 174p.

LAMARCA, E.V.; BARBEDO, C.J. Methodology of the tetrazolium test for assessing the viability of seeds of Eugenia brasiliensis Lam., Eugenia uniflora L. and Eugenia pyriformis Cambess. Journal of Seed Science, v.36, n.4, 2014. https://www.scielo.br/scielo. php?script=sci_arttext\&pid=S2317-15372014000400007

LANDRUM, L.R.; KAWASAKI, M.L. The genera of Myrtaceae in Brazil: an illustrated synoptic treatment and identification keys. Brittonia, v.49, n.4, p.508-536, 1997. https://link.springer.com/article/10.2307/2807742

LEÃO-ARAÚJO, E.F.; SANTOS, W.V.; FERREIRA, L.B.S.; FERREIRA, E.A.S.; GOMES-JÚNIOR, F.G.; PEIXOTO, N.; SOUZA, E.R.B. Embebição e emissão da raiz primária de sementes de Campomanesia adamantium em função da temperatura. Revista de Ciências Agrárias, v.42, n.2, p.111-120, 2019. http://www.scielo.mec.pt/scielo.php?script=sci_arttext\&pid=S0871-018X2019000200012

LORENZI, H. Árvores Brasileiras: manual de identificação e cultivo de plantas arbóreas nativas do Brasil. Nova Odessa: Instituto Plantarum, 2002. 368p. 
LORENZI, H.; BACHER, L.; LACERDA, M.; SARTORI, S. Frutas brasileiras e exóticas cultivadas: de consumo in natura. São Paulo: Instituto Plantarum de Estudos da Flora, 2006. 672p.

MAGUIRE, J.D. Speed of germination-aid in selection and evaluation for seedling emergence and vigor. Crop Science, v.2, n.2, p.176177, 1962. https://doi.org/10.2135/cropsci1962.0011183X000200020033x

MALUF, A.M.; PISCIOTTANO-EREIO, W.A. Secagem e armazenamento de sementes de cambuci. Pesquisa Agropecuária Brasileira, v.40, n.7, p.707-714, 2005. https://www.scielo.br/scielo.php?pid=S0100204X2005000700012\&script=sci_arttext

MARCOS-FILHO, J. Fisiologia de sementes de plantas cultivadas. Londrina: ABRATES, 2015. 660p.

OLIVEIRA, M.I.U.; COSTA, I.R.; PROENÇA, C.E.B. Campomanesia in Flora do Brasil. Jardim Botânico do Rio de Janeiro, 2020. http:// floradobrasil.jbrj.gov.br/reflora/floradobrasil/FB10324

SANTORO, M.B.; BROGIO, B.A.; FORTI, V.A.; NOVEMBRE, A.D.L.C.; SILVA, S.R. Desiccation tolerance of cambuci seeds. Comunicata Scientiae, v.11, e3143, 2020. http:// comunicatascientiae.com.br/comunicata/article/view/3143

SANTOS, M.A.C.; QUEIRÓZ, M.A.; BISPO, J.S.; DANTAS, B.F. Seed germination of Brazilian guava (Psidium guineense Swartz.). Journal of Seed Science, v.37, n.4, p.214-221, 2015. https://www.scielo.br/pdf/jss/v37n4/2317-1537-jss-37-04-00214.pdf

SARMENTO, M.B.; SILVA, A.C.S.; VILLELA, F.A.; SANTOS, K.L. Biometria de frutos e sementes e crescimento pós-seminal de Acca sellowiana (O. Berg. Burret) Myrtaceae. Caderno de Pesquisa, v.30, n.1, p.1-8, 2018. https://online.unisc.br/seer/index.php/ cadpesquisa/article/view/8696/7279

SARMENTO, M.B.; SILVA, A.C.S.; VILLELA, F.A.; SANTOS, K.L.; MATTOS, L.C.P. Teste de tetrazólio para avaliação da qualidade fisiológica em sementes de goiabeira-serrana (Acca sellowiana O. Berg Burret). Revista Brasileira de Fruticultura, v.35, n.1, p.270-276, 2013. http://www.scielo.br/pdf/rbf/v35n1/31.pdf

SILVA, A.L.; DIAS, D.C.F.S.; LIMA, L.B.; MORAIS, G.A. Methods for overcoming seed dormancy in Ormosia arborea seeds, characterization and harvest time. Journal of Seed Science, v.36, n.3, p.318-325, 2014. https://www.scielo.br/scielo.php?script=sci_ arttext\&pid=\$2317-15372014000300007

SILVA, A.L.; HILST, P.C.; DIAS, D.C.F.S.; ROGALSKI, M. Superação da dormência de sementes de Passiflora elegans Mast. (Passifloraceae). Revista Verde de Agroecologia e Desenvolvimento Sustentável, v.14, n.3, p.406-411, 2019. http://oaji.net/ articles/2019/2238-1574858454.pdf

SILVA, B.A.; NOGUEIRA, J.L.; VIEIRA, E.S.N.; PANOBIANCO, M. Critérios para condução do teste de tetrazólio em sementes de araucária. Pesquisa Agropecuária Brasileira, v.51, n.1, p.61-68, 2016. https://www.scielo.br/pdf/pab/v51n1/1678-3921pab-51-01-00061.pdf

SILVA, R.C.; GRZYBOWSKI, C.R.S.; FRANÇA-NETO, J.B.; PANOBIANCO, M. Adaptação do teste de tetrazólio para avaliação da viabilidade e vigor em sementes de girassol. Pesquisa Agropecuária Brasileira, v.48, n.1, p.105-113, 2013. http://www.scielo.br/ pdf/pab/v48n1/14.pdf

TOKAIRIN, T.O.; SILVA, A.P.G.; SPRICIGO, P.C.; ALENCAR, S.M.; JACOMINO, A.P. Cambuci: a native fruit from the Brazilian Atlantic forest showed nutraceutical characteristics. Revista Brasileira de Fruticultura, v.40, n.5, 2018. https://www.scielo.br/scielo. php?script=sci_abstract\&pid=S0100-29452018000500702\&lng=pt\&nrm=iso\&tlng=en

VALLILO, M.I.; GARBELOTTI, M.L.; OLIVEIRA, E.; LAMARDO, L.C.A. Características físicas e químicas dos frutos do cambucizeiro (Campomanesia phaea). Revista Brasileira de Fruticultura, v.27, n.2, p.241-244, 2005. https://www.scielo.br/scielo.php?script=sci_ arttext\&pid=S0100-29452005000200014

VAUGHTON, G.; RAMSEY, M. Sources and consequences of seed mass variation in Banksia marginata (Proteaceae). Journal of Ecology, v.86, p. 563-573, 1998. https://besjournals.onlinelibrary.wiley.com/doi/pdf/10.1046/j.1365-2745.1998.00279.x

WCZASSEK, L.R.; PONTES, V.C.B.; GAMBERINI, M.T. Pharmacological evaluation of the hydro-alcoholic extract of Campomanesia phaea fruits in rats. Brazilian Journal of Biology, v.80, n.3, 2019. https://www.scielo.br/j/bjb/a/qFZkcfVCNNcpnhbc58SXHgp/?lang=en 